\title{
Media Sosial dan Revolusi Politik: Memahami Kembali Fenomena "Arab Spring" dalam Perspektif Ruang Publik Transnasional $^{1}$
}

\author{
Ahmad Rizky Mardhatillah Umar ${ }^{2}$ \\ Arief Bakhtiar Darmawan ${ }^{3}$ \\ Faela Sufa ${ }^{4}$ \\ Gebyar Lintang Ndadari ${ }^{5}$
}

\begin{abstract}
This paper aims to analyze some linkages between revolution, public sphere, and transnational activism through social media in the Middle East. A revolution in Tunisia in 2011 became an international issue after the revolution spreaded to other states in the region. After Tunisia, protest movements began to ignite in Egypt, Libya, Yemen, and Jordania. This wave of revolution comes into a public discourse: what causes this movement? How could a revolution in one country inspire another revolution in another country? To answer these questions, we analyze the role of social media as a "bridge" to connect activists in the Middle East to make a revolution. We conclude that transnational activism was formed by routine and massive reports from media which explained what hadhappened in the Middle East during the revolution. The reports were followed by a spread of the idea of democracy and civil rights through social media. As a consequence, revolution took place in several other countries whose socio-cultural tradition are similar to that of Tunisia.
\end{abstract}

Keywords:

revolution; social media; transnational activism; public sphere.

\begin{abstract}
Abstrak
Tulisan ini bertujuan untuk menganilisis beberapa keterkaitan antara revolusi, ruang publik, dan aktivisme transnasional melalui media sosial di Timur Tengah. Sebuah revolusi di Tunisia pada tahun 2011 menjadi isu internasional setelah revolusi menyebar ke negara-negara lain di kawasan tersebut. Setelah Tunisia, gerakan protes mulai menyala di Mesir, Libya, Yaman, dan Yordania. Gelombang revolusi menjadi sebuah wacana publik: apakah penyebab gerakan ini? Bagaimana mungkin sebuah revolusi di satu negara menginspirasi negara lain untuk melakukan revolusi? Untuk menjawab pertanyaan ini, peran media sosial dianalisis sebagai "jembatan" yang menghubungkan para aktivis di Timur Tengah untuk membuat sebuah revolusi. Dapat

\footnotetext{
1 Penulis berterima kasih kepada Ririn Tri Nurhayati, MA (Dosen Jurusan Ilmu Hubungan Internasional UGM dan Kandidat PhD di University of Queensland) dan dua anonymous reviewer yang memberikan masukan-masukan konstruktif atas naskah tulisan ini. Draft awal tulisan ini adalah laporan dari penelitian mahasiswa yang dibiayai dalam skema Hibah Riset Mahasiswa FISIPOL UGM tahun 2011.

2 Peneliti di ASEAN Studies Center Universitas Gadjah Mada. Email: ahmad.rizky.m@mail.ugm.ac.id

3 Mahasiswa Pascasarjana Jurusan Ilmu Hubungan Internasional Universitas Gadjah Mada

4 Mahasiswa Pascasarjana Department of Public Policy Universitas Tokyo

5 Alumni Jurusan Ilmu Hubungan Internasional Universitas Gadjah Mada
} 
disimpulkan bahwa aktivisme transnasional dibentuk oleh pemberitaan rutin dan meluas dari media yang menjelaskan apa yang telah terjadi di Timur Tengah selama revolusi. Berita tersebut diikuti oleh penyebaran gagasan demokrasi dan hak-hak sipil melalui media sosial. Konsekuensinya, revolusi terjadi di beberapa negara lain dengan tradisi sosial budaya yang mirip dengan Tunisia.

\section{Kata Kunci:}

revolusi; media sosial; aktivisme transnasional; ruang publik.

\section{Pendahuluan}

Pada akhir tahun 2010 hingga pertengahan 2011, pemerintah beberapa negara Timur Tengah menghadapi serangkaian demonstrasi yang diorganisir oleh aktivis-aktivis pemuda. Gerakan demonstrasi ini, yang kemudian dikenal dengan "Arab Spring" bermula dari Provinsi Sidi Bouzid di Tunisia, ketika para demonstran menuntut turun rezim Zine al-Abidine Ben Ali atas buruknya situasi ekonomi, korupsi, dan tingginya tingkat pengangguran di Tunisia. Aksi mereka dipicu oleh percobaan bunuh diri seorang pedagang asongan bernama Mohamed Bouazizi. Bouazizi membakar diri setelah polisi menyita dagangan berupa buah dan sayur yang merupakan satusatunya sumber penghasilan. Bouazizi meninggal di rumah sakit pada 4 Januari 2011 akibat luka bakar dari aksinya. Dengan segera, Bouazizi menjadi simbol perlawanan rakyat atas rezim Ben Ali. Tidak kuat menghadapi demonstrasi dan kerusuhan-kerusuhan yang terus terjadi, Ben Ali akhirnya melarikan diri ke Jeddah, Arab Saudi. Larinya Ben Ali menandai berakhirnya rezim yang ia bangun sejak 24 tahun sebelumnya. Gerakan oposisi akhirnya bisa membangun transisi di Tunisia.

Kondisi serupa dihadapi oleh Mesir. Banyaknya kaum muda yang menganggur, tingginya korupsi di pemerintahan, serta kesenjangan antara kaya dan miskin yang semakin menjadi-jadi membuat rakyat turun ke jalan menuntut mundurnya Presiden Husni Mubarak. Gerakan massa yang terus terjadi sejak 25 Januari 2011 membuat Mubarak akhirnya mengundurkan diri dan menyerahkan pemerintahan kepada pihak militer (Said Ali,
2012). Dengan demikian, Mesir menjadi negara kedua yang berganti kepemimpinan akibat tekanan gerakan massa dalam Arab Spring.

Runtuhnya rezim Ben Ali dan Mubarak kemudian menyebar di negara-negara lain di kawasan Timur Tengah. Demonstrasi disertai kerusuhan terjadi di Aljazair, Yaman, Yordania, Suriah, Bahrain, dan Libya. Penyebabnya sama, yaitu korupsi, kemiskinan, dan angka pengangguran yang tinggi. Di Aljazair, misalnya, massa menuntut mundur Presiden Abdelaziz Bouteflika karena pemerintahannya dianggap tidak mampu mengatasi masalah harga makanan, kekurangan perumahan, serta ketidakpuasan politik dan sosial. Pemerintah Yordania juga dianggap oleh rakyatnya sebagai tidak mampu menurunkan harga bahan bakar dan harga kebutuhan pokok.

Fenomena gerakan massa di berbagai negara, yang berani menuntut mundur rezimrezim otoriter merupakan fenomena baru di kawasan Timur Tengah. Gerakan massa tersebut mengarah ke gelombang demokratisasi yang sebelumnya diduga tidak akan pernah berlangsung dalam konteks Timur Tengah. Mengapa gerakan massa melawan rezim otoriter terjadi dan menyebar di antara negaranegara Timur Tengah?

Tulisan ini mencoba untuk memberikan penjelasan mengenai perubahan politik di Timur Tengah sebagai sebuah fenomena tersendiri yang terjadi di kawasan tersebut, yang berbeda dengan fenomena serupa yang pernah terjadi di Asia Tenggara. ${ }^{6}$ Lebih jauh, tulisan ini berargumen

$\overline{6}$ Upaya serupa pernah dilakukan oleh Tomas Pepinsky 
bahwa revolusi Arab Spring sangat dipengaruhi oleh warga negara yang aktif menginisiasi gerakan politik dan perkembangan media sosial yang memungkinkan menyebarnya wacana tentang revolusi.

Perkembangan teknologi media sosial tersebut berjalan beriringan dengan pola aktivisme yang semakin canggih dan terjejaring, yang menghasilkan sebuah gerakan politik yang simultan di kawasan. Secara teoretis, dengan menggunakan konsep transnational activism yang dikemukakan oleh Snow dan Benford (2000) dan konsep public sphere dari Habermas (2010), teknologi memicu pembentukan "ruang publik politis" yang melampaui negara-bangsa dan memungkinkan pertarungan gagasan politik berlangsung di arena tersebut.

Pembahasan tulisan ini akan dibagi ke dalam lima bagian. Bagian pertama akan memaparkan secara teoretik kaitan antara ruang publik, aktivisme transnasional, dan perubahan politik. Bagian kedua akan menjelaskan setting politik di kawasan Timur Tengah menjelang terjadinya gelombang Arab Spring di tahun 2010-2011. Di bagian ketiga, tulisan ini akan memberikan paparan mengenai pertumbuhan media sosial, dan perannya dalam menyebarkan gerakan sosial-politik di Timur Tengah pada periode tersebut akan diuraikan di bagian keempat. Sementara itu, bagian kelima akan mengulas pembentukan "ruang publik" yang memungkinkan terjadinya perubahan politik di Timur Tengah melalui media sosial. Tulisan akan ditutup dengan kesimpulan.

\section{Ruang Publik, Aktivisme Transnasional, dan Perubahan Politik: Kerangka Teoritis}

Perubahan politik di Timur Tengah pada awal 2011 sering dijelaskan dengan adanya

yang mencoba untuk memberikan penjelasan mengapa pengalaman demokratisasi Indonesia tidak terulang di Mesir. Lihat Tom Pepinsky, "There is No Indonesian Model for the Arab Spring", Foreign Affairs,February 27, 2013. 'gelombang demokratisasi,' yang melihat gerakan politik Timur Tengah pada dasarnya merupakan gerakan demokratisasi yang ingin meruntuhkan otoriterisme dan menggantinya dengan proses transisi demokrasi (Grand, 2011; Howard dan Hassan, 2013;). Diilhami oleh teoriteori transisi demokrasi yang dikemukakan oleh Samuel Huntington (1993), perspektif ini berargumen bahwa Arab Spring adalah respons 'liberal' dari otoriterisme yang menghendaki liberalisasi politik dan demokratisasi di Timur Tengah.

Ada beberapa literatur yang menggunakan perspektif ini untuk memahami Arab Spring. Sebagai contoh, Grand (2011) menyebut gelombang aksi massa di Timur Tengah pada awal tahun 2011 sebagai gelombang keempat demokratisasi. Secara tradisional, kekuasaan otoriter yang terbangun di Timur Tengah melibatkan oligarki yang sangat kuat antara militer, modal internasional, dan pemimpin politik (lihat Arfani, 2011). Gerakan politik yang terjadi di Tunisia, dalam sudut pandang ini, adalah resultante politik dari ketidakpuasan massa yang menginginkan demokrasi setelah bertahun-tahun berada di bawah kepemimpinan otoriter Presiden Ben Ali. Dalam perspektif ini, gerakan massa lebih merupakan 'keniscayaan' dari runtuhnya rezim otoriter dan munculnya demokratisasi (Ahmad dan Cappocia, 2004; Kitchen et. al, 2011).

Perspektif lain menekankan Arab Spring sebagai proses demokratisasi yang terbangun secara alamiah (lihat Howard dan Hassan, 2011). Perspektif ini melihat bahwa proses demokratisasi akan tumbuh secara niscaya, karena adanya gerakan-gerakan sosial yang tumbuh dan menggunakan kemajuan teknologi yang ada untuk mengartikulasikan gerakannya. Penggunaan beberapa repertoar dan aksi-aksi nonkekerasan menunjukkan bahwa Arab Spring merupakan keniscayaan dari munculnya gerakan-gerakan prodemokrasi di Timur Tengah yang menginginkan adanya perubahan politik (Kurzman, 2012). 
Terdapat beberapa kritik dari pendekatan model transisi ini. Kalangan strukturalis mengkritik pendekatan ini karena gagal menjelaskan dinamika 'konsolidasi ekonomi pasar' yang menyertai proses demokratisasi (Hadiz, 2003). Proses demokratisasi yang berjalan pasca-otoriterisme gagal menjelaskan mengapa proses liberalisasi yang berjalan di sektor politik tidak diikuti oleh demokratisasi di sektor ekonomi, melainkan memuluskan jalan bagi pelembagaan kapitalisme secara massif (Hadiz, 2011). Dalam konteks Timur Tengah, pendekatan ini juga gagal menjelaskan fenomena bangkitnya kembali gerakan-gerakan Islamis dalam berbagai bentuk, yang dalam beberapa kasus seperti di Mesir dan Libya justru menghilangkan asumsi demokratis setelah "Arab Spring"(Chamkhi, 2012).

Selain dikritik secara teoritis, perspektif gelombang demokratisasi juga gagal menjelaskan mengapa setelah Arab Spring terjadi beberapa kasus kembalinya otoritarisme. Fenomena di Mesir menunjukkan bahwa walaupun rezim otoriter sudah berhasil dijatuhkan, pemilu yang kemudian dimenangkan oleh kalangan Islamis justru gagal membawa iklim politik yang demokratis (Pepinsky, 2013). Dalam konteks Suriah dan Yaman, fenomena Arab Spring justru diikuti oleh konflik berkepanjangan akibat kontestasi antara kekuatan-kekuatan politik yang saling menjatuhkan. Hal ini membuat perspektif gelombang demokratisasi kurang memberikan penjelasan yang utuh tentang fenomena Arab Spring.

Namun perspektif strukturalis, yang lebih menekankan penjelasan pada struktur ekonomi politik dan cenderung mengabaikan aspek agensi politik. Kita bisa bertanya secara lebih kritis apa yang menyebabkan gelombang perubahan politik di Timur Tengah menjadi mungkin setelah Arab Spring? Dalam perspektif Tariq Ramadan, hal ini dapat dilacak pada dua hal yaitu proyek demokratisasi politik yang difasilitasi oleh Amerika Serikat dan akses terhadap teknologi yang dimiliki oleh anakanak muda di Timur Tengah, yang kemudian bertemu dalam sebuah skema gerakan yang kompleks (Ramadan, 2012). Artinya, penjelasan tentang struktur ekonomi-politik bukanlah satu-satunya variabel yang mendorong Arab Spring, perlu dilihat konteks sosial lain yang juga berkontribusi terhadap proses perubahan yang terjadi.

Tulisan ini mencoba untuk memberikan penjelasan yang lebih memadai tentang munculnya Arab Spring beserta reversal (pembalikan) yang terjadi di beberapa negara setelah revolusi tahun 2011. Tulisan ini berargumen bahwa gerakan politik Timur Tengah pada awal 2011 terjadi karena ruang publik yang dibatasi di dalam negeri, sehingga massa mengakumulasikan kekecewaan mereka melalui ruang publik baru. Terdapatnya pembentukan wacana komunikatif di media sosial, sebagaimana diulas Al-Jazeera (2011), memperkuat argumen ini. Pembentukan wacana revolusi tidak lagi menggunakan jalan konvensional dengan sel-sel massa, seperti Ikhwanul Muslimin, tetapi dengan menggunakan dunia maya.

Kurangnya ruang publik terjadi karena otoriterisme membuat pemerintah memegang kuasa kuat untuk memata-matai semua bentuk aktivisme politik, yang berpotensi mengganggu eksistensi rezimnya. Aktivisme tidak memungkinkan terjadi di sel basis massa, oleh karenanya ia dijalankan di mediamedia sosial. Sifat jejaring media sosial yang transnasional membuat wacana meluas dari satu negara ke negara lain. Meminjam istilah Al-jazeera, media sosial menjadi "senjata baru" untuk melakukan aktivisme politik.

Untuk melihat relasi antara jejaring sosial dan gerakan massa, istilah"ruang publik" yang dijadikan pusat teori dari penelitian ini perlu didefinisikan. Menurut Habermas (2010: 41), ruang publik dipahami sebagai ruang orang-orang privat yang datang bersamasama sebagai publik, mereka mengklaim 
ruang tersebut sebagai milik publik yang tidak diatur dari atas (negara) sebagai (bentuk) kewenangan publik. Jika definisi ini digunakan secara konsisten, ruang publik tidak hanya didefinisikan ada dalam arti politik, tetapi juga ekonomi, sosial, bahkan budaya. Ruang publik adalah pengejawantahan rasionalitas publik dalam ruang-ruang artikulasi yang tersedia di masyarakat.

Dalam arti politik, ruang publik dipandang dalam konteks representasi politik. Habermas menyebutnya sebagai "fungsi politik ruang publik", yang bermakna ruang publik mampu menjadi arena bagi subjek-subjek politik tertentu untuk mengartikulasikan kepentingankepentingan mereka (Habermas, 2010: 81). Terdapatnya ruang publik membuat protesprotes dapat tersalurkan dan gerakan massa bisa terkonsolidasi. Oleh sebab itu, dalam perspektif ini, ruang publik perlu dipahami dalam kaitannya dengan artikulasi kepentingan politik. Dalam konteks masyarakat otoritarian, ruang publik menjadi lokasi bagi kekuatankekuatan politik yang termarjinalkan untuk menyuarakan aspirasinya serta menggalang dukungan guna berkontestasi dengan kekuatan status quo.

Perspektif ruang publik penting dalam memberikan alternatif penjelasan mengenai alasan Arab Spring bisa menjadi isu regional, alih-alih hanya terkonsentrasi di Tunisia atau Mesir. Berbeda dengan penjelasan gelombang demokratisasi yang percaya bahwa revolusi Arab Spring akan serta-merta berdampak pada proses demokratisasi dan transisi, perspektif ini melihat bahwa pertarungan politik yang mengiringi Arab Spring akan sangat berkaitan dengan perebutan ruang publik. Demokratisasi hanya akan bermakna jika ada perdebatan atau dialog di antara semua kekuatan politik yang berlangsung di ruang publik (Singh and Takur, 2013).

Dalam perspektif ini, demokratisasi merupakan proses-proses perebutan ruang publik, di antara semua kekuatan politik, termasuk negara dan masyarakat sipil. Persoalannya, bagaimana ruang publik tersebut dapat digunakan untuk melakukan tindakantindakan yang bernilai sosial maupun politik? Habermas mengajukan tawaran berupa demokrasi melalui tindakan komunikatif. Proses transfer legitimasi kepada rakyat sebagai artikulasi demokrasi dilakukan melalui wacana komunikatif antarwarga dengan medium ruang publik.

Menurut Habermas, seperti yang digambarkan oleh Hardiman (2010), sebuah legitimasi publik dibawa oleh suatu proses transfer antara massa dan elit politik yang dilakukan melalui wacana komunikatif. Melalui tindakan komunikatif tersebut, ruang publik menjelma menjadi ruang publik politis. Dalam konteks gerakan massa, proses bagaimana massa dapat digerakkan untuk melawan rezim otoriter terjadi melalui wacana komunikatif di ruang publik tersebut.

Jika perspektifini dikaitkan dengan revolusi Timur Tengah, akan muncul sebuah pertanyaan: bagaimana revolusi di sebuah negara bisa menyebar ke negara-negara lain dalam jangka waktu singkat? Jawaban sementara yang paling memungkinkan adalah terdapatnya fenomena aktivisme transnasional, seperti diungkap David Snow dan Richard Benford (1998). Perspektif transnasional mengimplikasikan terdapatnya pendekatan aktor non-negara dalam membaca isu-isu kontemporer dalam kajian Hubungan Internasional, termasuk soal arus informasi yang kian tidak dapat dikendalikan oleh negara.

Proses globalisasi yang berpadu dengan perkembangan teknologi informasi mengimplikasikan semakin berkembangnya media massa. Kini, media jejaring sosial menjadi alat baru untuk menyampaikan informasi dan menjalankan aktivisme transnasional. Sifatnya yang melewati batas negara dan pengaruhnya secara sosial menjadikan media baru ini perlu dianalisis. Dalam aktivisme transnasional, Snow dan Benford (1988) 
memperkenalkan konsep "framing"sebagai mode transnasionalisasi gerakan.

Framing didefinisikan oleh Snow dan Benford sebagai "the use of external symbols to orient local or national claims." Konteks politik Timur Tengah menggeser pemaknaan ini, framing tidak hanya berarti penggunaan simbol, tetapi juga terdapatnya substansi yang sama akibat mode otoriterisme yang tak jauh berbeda. Leksono (2011) menyatakan bahwa teknologi informasi mempercepat proses penyebaran wacana, sehingga proses framing berjalan lebih cepat. Jejaring sosial menjadi alat untuk mempercepat penyebaran wacana tersebut, termasuk yang mengarah kepada perubahan politik.

\section{Setting Politik Timur Tengah Kontemporer}

Istilah "Timur Tengah" muncul dalam studi-studi orientalisme klasik dan berkembang menjadi kategori kawasan dalam kajian Hubungan Internasional (lihat Said, 1978; Halliday, 2005). Istilah ini lekat dengan faktor etnokultural dan etnoreligi. Secara etnokultural, penggolongan negara-negara dalam kawasan Timur Tengah didominasi oleh bangsa Arab. Sementara dari faktor etnoreligi, sebagian besar kawasan ini didominasi oleh pengaruh agama Islam. Kedua faktor ini menjadi satu paduan yang tidak bisa dipisahkan sehingga kawasan Timur Tengah sering juga disebut dengan “Dunia Arab dan Islam." Kedua faktor tersebut membuat sebagian negara di Afrika bagian utara termasuk dari kawasan Timur Tengah, yaitu Aljazair, Maroko, Mauritania, Libya, Sudan (pengecualian untuk Sudan Selatan yang baru saja memerdekakan diri dari Sudan), Mesir, Somalia, Tunisia, dan Djibouti. Mereka bergabung dengan Yordania, Arab Saudi, Yaman, Uni Emirat Arab, Oman, Qatar, Bahrain, Irak, Iran, Kuwait, Palestina, Turki, Israel, Lebanon, dan Suriah di benua Asia.

Pada umumnya, negara-negara di Timur Tengah merupakan eksportir minyak dunia.
Meski demikian, sejumlah negara di kawasan ini juga tercatat sebagai importir minyak (IMF, 2011). Secara politik, sebagian besar rezim di Timur Tengah adalah diktator dan otoriter. Hal ini bisa diamati dari beberapa fenomena menarik yang khas. Pertama, partisipasi politik dan keberadaan partai politik sangat terbatas. Di Mesir, Maroko, dan Yordania, misalnya, pelaksanaan pemilu dan pihak oposisi mendapat tekanan dan kontrol yang sangat ketat dari rezim berkuasa yang otoriter. Di Arab Saudi, Bahrain, dan Uni Emirat Arab, sama sekali tidak boleh ada partai politik. Sementara itu, rezim-rezim diktator Irak, Libya, dan Suriah melarang berkembangnya partai oposisi.

Kedua, pemimpin-pemimpin di Timur Tengah jarang meraih kekuasaan melalui pemilu. Kebanyakan pemimpin yang berkuasa saat ini, atau setidaknya satu generasi kepemimpinan sebelumnya, meraih kekuasaan dengan cara melakukan kudeta atau melalui pewarisan. Contoh pemimpin Timur Tengah yang meraih kekuasaan dengan kudeta adalah Moammar Qadhafi(Libya, 1969), Saddam Husein(Irak, 1979), Al-Basyir (Sudan, 1989), Hafiz Al-Asad (1970), A. Saleh (1978), dan yang baru saja runtuh, yaitu Zine Abidine Ben Ali (Tunisia, 1987). Sedangkan pewarisan dilakukan, misalnya, oleh Arab Saudi (keluarga As-Saud) dan Bahrain (Hamad bin Isa, sebelumnya Syaikh Isa). Pewarisan kekuasaan juga dilakukan di Kuwait, Yordania, dan Maroko.

Ketiga, terdapat kecenderungan menarik akan identitas agama dan sistem politik. Meskipun identitas Islam mendominasi kuat di kawasan ini, namun partai politik atau gerakan Islam sendiri diberangus oleh rezim yang berkuasa. Berbeda dengan Iran yang memberikan hak hidup bebas kepada partai Islam, negara-negara seperti Mesir, Aljazair, dan Irak melarang berkembangnya partaipartai Islam. Sebagai contoh, gerakan Islam Ikhwanul Muslimin, bahkan dinyatakan sebagai partai terlarang di negeri asalnya, Mesir. Meski kemudian gerakan ini sempat berkuasa ketika 
Mohammad Mursi menggantikan Mubarak sebagai presiden. Di Aljazair, kemenangan besar partai Islamic Salvation Front (Front Pembebasan Islam) pada pemilu di tahun 1989 bahkan harus berakhir tragis akibat pembantaian oleh pemerintah (Internationale, 2011).

Sistem politik Timur Tengah dengan tiga fenomena di atas membuat kawasan ini tidak memiliki gejolak politik yang berat. Setiap kali muncul peluang untuk terjadinya suatu pemberontakan, rezim segera bertindak represif untuk mempertahankan kekuasaan mereka. Otoriterisme ini bertahan sangat lama. Bahkan, Mesir mengalami otoriterisme dan berada di bawah rezim militer sejak 1950-an sampai kemudian terjadi Arab Spring (Zahid, 2010). Namun, rezim-rezim yang diktator dan absolut tersebut bisa runtuh oleh gerakan massa yang terjadi pada tahun 2011. Setelah Tunisia, pada 4 Januari 2011 muncul demonstrasi massa serupa di Aljazair. Di Yaman, terjadi gerakan pada tanggal 20 Januari, yang menyebabkan Presiden Ali Abdullah Saleh langsung mengumumkan akan meletakkan jabatan pada tahun 2013 dan tidak akan berkuasa lagi.

Gerakan massa selanjutnya, yang terkuatdan berhari-hari diliput berbagai media internasional dengan intens, terjadi di Mesir. Ribuan orang berkumpul di Lapangan Tahrir mengecam tingginya harga pangan, kurangnya lapangan pekerjaan, korupsi, dan sistem pemerintahan yang otoriter. Desakan dan kerusakan yang terjadi akhirnya membuat Husni Mubarak mengundurkan diri dan menyerahkan kekuasaan. Demonstrasi juga terjadidi Yordania, Suriah, dan Bahrain. Di Yordania, rakyat mengecam tingginya harga bahan bakar dan bahan-bahan kebutuhan pokok. Di Suriah, korupsi, angka pengangguran yang tinggi, dan kemiskinan membuat rakyat melakukan aksi menentang Presiden Bashar al-Assad.

Kronologi revolusi yang bisa dibaca sebagai efek domino dari gejolak di Tunisia dan Mesir tersebut memperlihatkan beberapa penyebab. Pertama, tingkat pengangguran dan angka kemiskinan yang tinggi. Tingkat pengangguran di sejumlah negara Timur Tengah pada tahun 2009 ialah Tunisia 14,1\%; Mesir 8,4\%; Aljazair 12,5\%; Yaman 35\%; Yordania 12,6\%; Suriah 86\%; Bahrain 15\%; Maroko 10\%; dan Libya 30\% (Hanouz dan Khatib, 2011). Kebanyakan pengangguran berasal dari warga dengan usia muda dan produktif, khususnya yang berusia di bawah 30 tahun (Ghosh, 2011b: 5).

Di sisi lain, beberapa negara di Timur Tengah juga merupakan penerima bantuan internasional yang cukup besar. Pada tahun 2008, secara per capita, negara-negara di Timur Tengah dan Afrika Utara mendapatkan bantuan finansial $\$ 73$ per kepala. Sementara itu, hampir 13\% dari GDP Yordania, misalnya, berasal dari suntikan dana remittance (Maleek dan Awadalah, 2011). Hal ini mengindikasikan adanya ketimpangan dan tingkat kemiskinan yang cukup tinggi di Timur Tengah dan Afrika Utara.

Kedua, tingkat pengangguran yang tinggi dan kemiskinan yang melanda di negaranegara Timur Tengah diperparah dengan kenaikan harga-harga barang. Ini membuat kondisi perekonomian dari kebanyakan negara di Timur Tengah semakin memburuk. Sejumlah negara yang mengalami revolusi memiliki GDP per kapita yang rendah dan account balance yang negatif. Tabel 1 berikut menggambarkan keterpurukan negara-negara Timur Tengah dan Afrika Utara menjelang Arab Spring.

Ketiga, penyebab lain yang melatarbelakangi revolusi di Timur Tengah ialah korupsi. Tingkat korupsi di negaranegara tersebut ditunjukkan dengan peringkat persepsi akan korupsi yang mereka peroleh pada Corruption Perception Index (CPI) yang dikeluarkan oleh Transparency International (TI) pada tahun 2010. Pada CPI 2010 yang memeringkatkan 178 negara itu, Tunisia berada pada peringkat ke-59 dengan nilai 4,3; Mesir pada peringkat ke-98 dengan nilai 3,1; 
Aljazair pada peringkat ke-105 dengan nilai 2,9; Yordania pada peringkat ke-50 dengan nilai 4,7; Suriah pada peringkat ke-127 dengan nilai 2,5; Maroko pada peringkat ke-85 dengan nilai 3,4; serta Yaman dan Libya pada peringkat yang sama, yaitu ke-146 dengan nilai 2,2 (Transparency International, 2011).

Korupsi yang terjadi di negara-negara Timur Tengah tidak hanya berupa petty corruption, namun juga korupsi berskala besar serta yang melibatkan birokrasi dan korupsi politik. Korupsi di negara-negara Timur Tengah telah menciptakan kerugian sebesar $\$ 1$ triliun, Menurut Arab Anti-Corruption Organisation, bila tidak dikorupsi, dana sebesar itu dapat digunakan untuk peningkatan pendapatan, pengurangan kemiskinan, dan memenuhi kebutuhan makanan dan air secara mandiri.

Keempat, ketidakpuasan terhadap sistem politik otoriter. Represi yang selama ini begitu kuat dirasakan oleh rakyat terhadap kebebasan dan hak-hak warga membuat mereka putus asa dan lelah. Namun, keempat pemicu sebelumnya, yang semakin parah dirasakan oleh rakyat, telah membuat keputusasaan mereka berubah menjadi perasaan tidak takut lagi pada rezim otoriter, yang sangat mungkin melakukan tindakan represif dengan menggunakan kekuatan militer.

Para pemuda di Timur Tengah dengan cepat merespon keempat sebab di atas. Secara umum, mereka menjalankan berbagai kegiatan yang kemudian menyebar dan memicu revolusi di Timur Tengah. Dalam sebuah survei, ditemukan bahwa $56 \%$ pemuda Timur Tengah menggunakan internet setiap hari, $54 \%$ menonton acara berita terpercaya di televisi, $67 \%$ sangat menyadari tingginya biaya hidup yang mereka hadapi, dan 30\% menginginkan untuk pindah secara permanen ke negara lain apabila memungkinkan (Ghosh, 2011a). Peta survei tersebut dapat dilihat pada Gambar 1.

\section{Gambar 1.}

\section{Peta Persebaran Pemuda dan Aktivitas Penggunaan Teknologi}

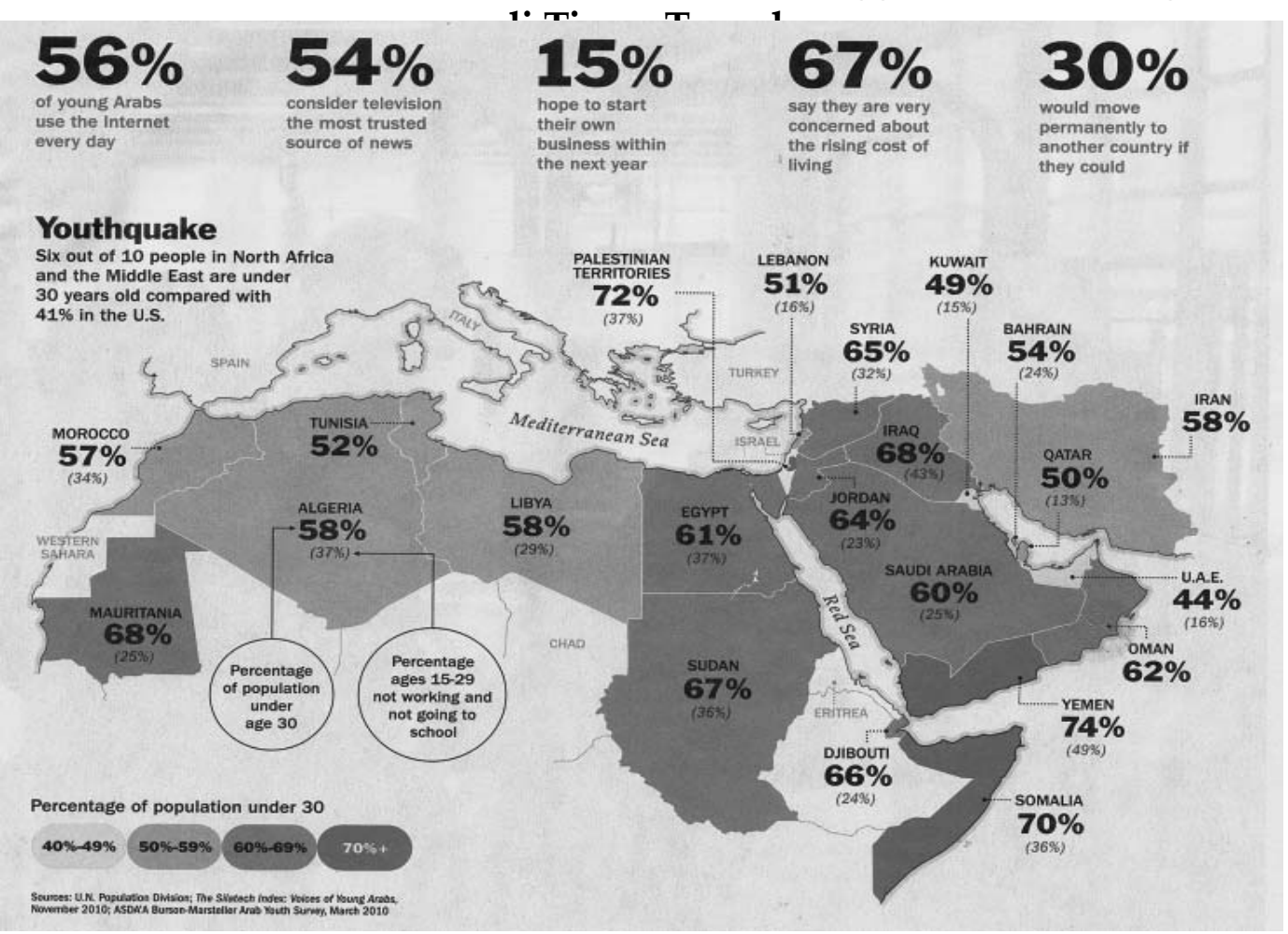

Sumber: Ghosh, $2011 b$. 
Warga muda yang semakin paham teknologi merupakan bagian penting dari menyebarnya aktivisme gerakan massa yang bekerja secara transnasional. Di Mesir, keterlibatan eksekutif Google, Wael Ghonim, misalnya, menjadi aset tersendiri bagi gerakan pemuda Timur Tengah dalam revolusi. Keberadaan teknologi yang sudah diterima luas oleh para pemuda, seperti televisi satelit, ponsel, komputer, dan internet berperan penting dalam penyebaran informasi. Teknologi dapat digunakan sebagai sarana edukasi, informasi, dan menghubungkan orang-orang dalam satu kawasan yang merasa senasib sependeritaan, untuk membentuk sebuah gerakan massa menuntut perubahan politik di Timur Tengah.

\section{Media Sosial dan Revolusi Timur Tengah}

Revolusi di Timur Tengah tak lepas dari peran media sosial dan teknologi yang menyebabkan revolusi tersebut menjalar secara transnasional. Bagaimana media sosial berperan secara signifikan? Secara teoritik, media sosial adalah salah satu bentuk new media (media baru). Media baru tidak hanya berperan dalam penyebaran informasi, melainkan juga memungkinkan semua orang untuk berkomunikasi dan berinteraksi secara dua arah. ${ }^{7}$ Secara umum, terdapat tiga elemen penting dari new media yang menyebabkan ia memiliki fungsi sosial, yaitu communication, convergence, dan content (3C). Berbeda dari media massa tradisional yang menggunakan hanya "satu bentuk" untuk semua orang, new media

\footnotetext{
Salah satu bentuk media baru ini adalah jejaring media sosial seperti Facebook, Twitter, serta yang kemudian muncul seiring dengan perkembangan gadget, yaitu Whatsapp dan Line. Jenis-jenis media baru ini kemudian berkembang di kalangan generasi muda, tak terkecuali di Timur Tengah. Meskipun tidak didesain untuk mempunyai peran politis, munculnya beberapa eksekutif media seperti Wael Ghonim di Mesir membuat media-media sosial ini segera terlibat dalam pergulatan politik yang ada di kawasan.
}

bersifat "satu untuk satu" dan konsekuensinya terfragmentasi pada kelompok-kelompok sosial tertentu, yang memiliki akses dan kapabilitas teknologi untuk menggunakannya. ${ }^{8}$

Lebih lanjut, menurut Adiputera, manfaat new media sangat tergantung pada bagaimana seseorang menggunakan ia sebagai bentuk komunikasi dan penyaluran informasi. Di sini, arus informasi dikendalikan oleh pengguna, bukan lagi oleh penyedia media. Ini berbeda dengan media massa tradisional yang menyajikan informasi secara terbuka, namun terbatas. Sebagai contoh, dapat dilihat bahwa ponsel digunakan untuk kepentingankepentingan pengguna dengan cepat dan langsung. Ini menjelaskan mengapa pergerakan massa di Timur Tengah begitu cepat menyebar ke antarnegara, karena pola komunikasinya cepat dan langsung merujuk kepada persoalan yang ada.

Jejaring sosial selalu dilihat dari beragam konteks: sosiokultural, politik, dan lain-lain. Pada posisi kultural, jejaring sosial menjelaskan bagaimana seseorang merepresentasikan diri dan kelompoknya pada basis sosial. Secara politik, jejaring sosial bisa menjadi media artikulasi kepentingan yang lebih luas. Hal ini mengilustrasikan perkembangan media dari pencarian informasi menjadi keterkaitan antar-individu, yang menjadi salah satu variabel penting dalam membangun pengorganisasian serta gerakan sosial. Dalam konteks ini new media bisa digunakan sebagai alat menyampaikan sesuatu dan mengajak kepada perubahan.

Di beberapa negara Timur Tengah, walaupun anti-Barat, akses internet dibuka karena masyarakat sudah paham media dan teknologinya bisa dibeli. Konsekuensi dari daya beli teknologi yang semakin tinggi dan masyarakat yang semakin melek media ini adalah munculnya kelas menengah.

\footnotetext{
8 Wawancara Wisnu Martha Adiputera, Staf Pengajar Jurusan Ilmu Komunikasi UGM, pada 30 Juni 2011.
} 
Munculnya kelas menengah ini juga diiringi oleh perubahan struktur ekonomi politik di Timur Tengah, akibat Oil Boom di pertengahan tahun 1970an, serta kebijakan pintu terbuka yang diberlakukan di Afrika Utara.

Di beberapa negara, misalnya Mesir dan Tunisia, kelas menengah tumbuh dan menjadi salah satu basis gerakan Islam yang cukup kuat (lihat Wickham, 2003; Zahid, 2010). Namun, ada dua masalah yang muncul. Pertama, beberapa negara tersebut adalah negara-negara yang secara politik berada di bawah kekuasaan rezim otoritarian, sehingga menghambat artikulasi politik kelas menengah. Kedua, kedua negara tersebut mengalami kondisi sosial-ekonomi yang sulit di pertengahan tahun 2010-2011, sebagai imbas langsung dari krisis ekonomi global. Pergerakan massa yang didominasi oleh kelas menengah, di Mesir dapat dilihat pada Gerakan 6 April atau Kifaya, merupakan respons dari krisis ekonomi domestik serta minimnya akses politik kelas menengah tersebut. ${ }^{9}$

Menurut Faris Al-Fadh, masalah yang muncul di Timur Tengah adalah kebebasan masyarakat yang dibatasi secara politik dan direpresi oleh negara, sehingga rakyat menjadi tidak puas. Mesir dan Tunisia adalah dua contoh menarik dimana otoriterisme politik merepresi gerakan-gerakan oposisi, termasuk gerakan Islamis dan gerakan-gerakan sosialdemokrasi. Di satu sisi, krisis membuat pergerakan tidak terhindarkan di awal tahun 2011. Di sisi lain, revolusi yang terjadi di kedua negara itu saat ini tak ada kaitannya dengan revolusi yang terjadi sebelumnya.

Di Mesir, revolusi yang terjadi pada tahun 2011 sangat berbeda, baik dengan

\footnotetext{
9 Kajian yang dilakukan oleh Mohammad Zahid sebelum Arab Spring merefleksikan hal ini. Menurut Zahid, politik infitah yang diinisiasi oleh Anwar Sadat pada tahun 1970an, diteruskan oleh Mubarak, berimplikasi pada munculnya kelas-kelas menengah yang secara politik sadar dan mulai membangun gerakan oposisi baru di tahun 2000an. Gerakan Kifaya dan 6 April adalah refleksi dari mulai terlibatnya kelas menengah dalam politik di Mesir, walaupun tidak secara langsung dan menggunakan media-media teknologi.
}

gerakan-gerakan yang diinisiasi oleh Ikhwanul Muslimin atau revolusi di tahun 1953. Proses revolusi Timur Tengah pada tahun 2011 dimulai oleh anak-anak muda yang tidak bersentuhan dengan ideologi. Mereka tidak berada dalam satu payung organisasi yang sama. Selain itu, revolusi juga didukung oleh penggunaan teknologi dan informasi yang menjadi simbol kelas menengah. Di Libya, menurut Faris, tidak adanya ruang publik menjadi pemicu utama dari tuntutan perubahan yang akhirnya berimplikasi pada gerakan massa menuntut mundurnya Moammar Khadhafi. ${ }^{10}$

Di Timur Tengah, pengaturan terhadap alat komunikasi memang ada, tetapi akses informasi tidak akan tertutup karena sifatnya terdesentralisasi. Pada tahun-tahun revolusi, internet sangat terkait dengan isu-isu politik karena ia berhubungan dengan informasi yang punya nilai berita. Persoalannya, di Timur Tengah dan negara-negara lain dengan kultur otoritarian, internet tidak dapat diakses dengan cukup bebas. Dalam hal ini, aktivitas penyaluran informasi publik biasanya akan sangat terkait dengan isu keamanan nasional yang menjadi domain pihak militer untuk menuntaskannya. ${ }^{11}$

Selain media sosial, revolusi di Timur Tengah juga menggunakan blog untuk menyalurkan pendapat politik. Blog menjadi sarana bagi kalangan muda Ikhwanul Muslimin Mesir untuk berekspresi, menjadi ruang swakritik, berdiskusi dan berdialog dengan kelas menengah dan elite senior Ikhwan (AlAnani, 2011; Hauslohner, 2011). Ada tiga tahap perkembangan blog sebagai sebuah media gerakan politik dalam konteks Ikhwanul Muslimin di Mesir (Al-Anani, 2011).

Pertama, tahap eksplorasi, yakni tahap ketika para blogger melakukan eksplorasi manhaj, aktivitas, agenda penting dan isu-isu

\footnotetext{
${ }^{10}$ Wawancara Faris Alfadh, Asisten Dosen Jurusan Ilmu Hubungan Internasional UMY pada 5 Juli 2011.

${ }^{11}$ Wawancara Faris Alfadh, Asisten Dosen Jurusan Ilmu Hubungan Internasional UMY pada 5 Juli 2011.
} 
internal organisasi melalui blog. Mereka tidak langsung secara frontal melakukan kritik terhadap rezim, melainkan dengan terlebih dulu melakukan eksplorasi isu dan wacana. Kedua, tahap resistensi sipil, yang muncul ketika revolusi terjadi. Blog pada fase ini menjadi simbol perlawanan politik melalui aktivitas propaganda. Tercatat sekitar 40 blogger yang awalnya mengawali perlawanan sipil melalui media maya di Mesir, sehingga blog mempunyai dimensi sosial-politiknya sendiri. Ketiga,swakritik, yang terjadi setelah revolusi. Pada tahap ini para blogger mulai melakukan kritik ideologi, berdiskusi, berdebat akan halhal yang bersifat kritis.

Ketiga, blog tidak hanya menjadi media perlawanan sosial-politik, tetapi juga mengembangkan wacana demokratisasi yang lebihluas. Tahapterakhirini kemudian bersesuaian dengan berkembangnya aktivisme transnasional di Timur Tengah. Gelombang demokratisasi muncul seiring dengan transnasionalisme dan pemanfaatan ruang publik sebagai bagian dari revolusi di kawasan ini.

Dengan demikian, dapat terlihat bahwa ada hubungan antara proses demokratisasi dengan terbukanya ruang-ruang publik di Timur Tengah yang direpresentasikan oleh media-media baru. Dalam konteks ini, media baru menjadi pendorong proses demokratisasi yang berjalan secara perlahan-lahan. Keberadaan media menjadi penting ketika terjadi krisis ekonomi, yang pada gilirannya menjadi momentum bagi kaum oposisi untuk mengonsolidasikan gerakannya.

\section{Peran Aktivisme Transnasional: Menjelaskan Penyebaran Gerakan Massa di Timur Tengah}

Gerakan massa yang menuntut mundurnya rezim-rezim otoriter di berbagai negara Timur Tengah adalah sebuah fenomena yang menarik untuk diamati. Dalam jangka waktu kurang dari dua bulan, generasi muda
Timur Tengah berhasil mendorong perubahan politik dalam skala yang sangat besar sebagai wujud dari aktivisme transnasional. Bagian ini akan memberikan ulasan bagaimana aktivisme transnasional menjadi salah satu variabel penting dalam proses perubahan politik di Timur Tengah.

Dalam kajian-kajian Hubungan Internasional, transnasionalisme menjadi tema yang mulai dibicarakan sejak akhir 1980-an. Menurut James Rosenau, transnasionalisme adalah proses di mana hubungan internasional yang dilangsungkan oleh pemerintah telah disertai oleh hubungan antara individu, kelompok, dan pihak swasta. Proses hubungan ini memiliki konsekuensi penting bagi dunia internasional (lihat Jackson dan Sorensen, 2007: 101). Transnasionalisme melihat negara bukan lagi aktor utama dalam setiap interaksi hubungan internasional.

Dalam konteks reformasi di Timur Tengah, aktor di balik transnasionalisme adalah individu dan kelompok-kelompok individu, terutama para pemuda. Namun, transnasionalisme bukan penyebab langsung revolusi di Timur Tengah, melainkan dampak dan resultante politik dari ketidakpuasan rakyat atas rezim yang berkuasa. Transnasionalisme bersifat instrumental atas perubahanperubahan politik. Pada titik ini, peran media sosial sebagai sebuah alat penyebaran wacana revolusi menjadi signifikan. Berkat peran media sosial, ketika perlawanan rakyat Tunisia berhasil meruntuhkan rezim Ben Ali yang telah berkuasa selama 24 tahun, masyarakat di negara-negara tetangga di Timur Tengah mulai berani untuk mengambil langkah yang sama.

Aktivitas transnasional di Timur Tengah dalam konteks Arab Spring dapatdipahami melalui dua perspektif. Pertama, transnasionalisme dapat dilihat melalui attitude change atau perubahan perilaku. Kedua, transnasionalisme dipahami dengan interpretasi atas fakta bahwa generasi muda Timur Tengah memaknai simbol-simbol yang terdapat di luar negara ke dalam gerakan 
mereka. Pemaknaan simbol ini berujung pada satu kesimpulan, yakni penilaian bahwa terdapat kesamaan struktur antara negara mereka dengan mayoritas negara lain di Timur Tengah.

Meminjam argumen Sidney Tarrow, fenomena ini adalah salah bentuk aktivisme transnasional yang menggunakan metode dan taktik-taktik framing sebagai instrumen gerakannya. Artinya, dengan menggunakan kerangka berpikir seperti ini, media baru, dalam hal ini media sosial dan blog, menjadi penting untuk menyampaikan simbol-simbol dan pesan gerakan yang dibangun oleh para aktivis (Tarrow, 2005).

Pada era globalisasi, transnasionalisme akan berimplikasi pada suatu proses transformasi. Mereka yang berinteraksi akan saling mengadopsi pengetahuan yang kemudian akan mendorong perubahan perilaku. Dalam konteks Timur Tengah, perubahan perilaku terjadi di tingkat akar rumput, terutama pada generasi muda. Di satu sisi, interaksi transnasional yang intens membuat generasi muda Timur Tengah sadar bahwa mereka berhak akan kebebasan dan kehidupan yang lebih sejahtera seperti yang diperoleh oleh orang-orang lain di luar negeri mereka (Ghosh, 2011b). Di sisi yang lain, sebagaimana diungkapkan Michele Angrist, gerakan massa yang semula hanya terjadi di Tunisia dan Mesir menjadi pemicu untuk lahirnya gerakan yang serupa di negara lain karena para aktivis transnasional sadar bahwa rezim otoriter juga hadir di negara lain (Angrist, 2011; Ghosh, 2011a).

Hambatan politik menyebabkan persebaran gagasan lintas negara secara fisik sulit dilakukan. Perkembangan teknologi membantu para aktivis transnasional berinteraksi secara tidak langsung melalui dunia maya. Aktivisme transnasional yang berlangsung di Timur Tengah berhasil memanfaatkan ruang publik melalui jejaring media sosial. Hassan Nafaa, seorang profesor ilmu politik di Universitas Kairo, menyebut para pemuda sebagai "the
Internet Generation or the Facebook Generation or just call them the Miracle Generation." (Ghosh, 2011a).

Kedua, transnasionalisme juga perlu dipahami sebagai basis penting dalam pembentukan ruang publik yang melampaui konstruksi negara bangsa. Dalam konteks transnasionalisme di Timur Tengah, jejaring sosial memiliki peran penting untuk membentuk ruang publik. Menurut Habermas, ruang publik merupakan sebuah ruang yang sangat kondusif bagi perkembangan masyarakat. Ruang publik hanya dapat mencapai fungsinya ketika situasi berpendapat yang ideal telah terwujud. Di Timur Tengah, media baru mempertemukan situasi berpendapat antara warga di berbagai negara, yang sebelumnya terbatas akibat sistem politik yang otoriter. Tidak adanya kontrol yang cukup dari pemerintah terhadap perkembangan media baru mendorong protesprotes massa beralih ke media, terakumulasi di antara gerakan massa yang bersifat nasional dan kemudian menjalar ke tingkat regional.

Ruang publik dalam konteks ini menjadi bersifat transnasional dan tidak lagi terbatas oleh batas negara-bangsa. Ruang publik dapat menjadi sebuah penghubung interaksi antara para pemegang kekuasaan dengan masyarakat mengingat dialog-dialog dalam ruang publik dapat menjadi refleksi keinginan masyarakat. Di beberapa negara, misalnya Mesir, ruang publik tersebut terhambat akibat pemerintah yang otoriter (lihat Zahid, 2010). Akibat pengaruh transnasional, gerakan massa di dalam negeri menguat dan mengambil inspirasi dari negara lain. Oleh karena itu, melalui ruang publik inilah dapat lahir suatu bentuk masyarakat yang ideal,bebas dari penindasan, dan dapat mengatasi krisis yang menghadang mereka (Kellner, 2011).

Keberadaan ruang publik akan sangat membantu masyarakat untuk mengungkapkan pendapat mereka dengan lebih merdeka. Selama ini, di negara-negara seperti Mesir dan Libya, partisipasi politik dan aspirasi rakyat 
dibatasi. Di Mesir, partai oposisi mendapat tekanan yang kuat dari rezim yang berkuasa, sementara di Libya partai oposisi bahkan dilarang berkembang. Di Tunisia, partai-partai Islam, yang menjadi saluran aspirasi sebagian kelompok, dilarang berdiri. Jejaring sosial telah berhasil menyediakan kebutuhan akan ruang publik yang selama ini diperlukan oleh masyarakat di Timur Tengah (Sihbudi, 1991:34; Chamkhi, 2012).

Keunggulan jejaring sosial adalah akses yang hampir tak terbatas dan tanpa kontrol negara. Jejaring sosial telah menjadi sebuah ruang publik, masyarakat dapat berinteraksi dengan leluasa. Sifat jejaring sosial yang sulit untuk dikontrol telah membantu masifnya gerakan massa yang terjadi di Timur Tengah pada awal tahun 2011 yang lalu gagal dibendung pemerintah. Jejaring sosial bahkan melintasi batas negara, membuat efek domino dari revolusi di sebuah negara menyebar ke negara-negara sekitar.

Menurut Ninok Leksono, mengikuti analisis David Kirkpatrick dan David Sanger dalam The New York Times, jejaring sosial telah membuat leluasanya aliran tukar-menukar info antar-aktivis prodemokrasi di Tunisia dan Mesir. Ketika para demonstran Mesir menghadapi aparat keamanan, mereka telah mendapat nasihat atau anjuran dari rekan mereka di negara lain, yaitu pendemo di Tunisia (Leksono, 2011). Sebagai contoh, para demonstran dianjurkan untuk menaruh jeruk, cuka, atau bawang di bawah scarf sebagai upaya menangkal gas air mata. Untuk keperluan yang sama mereka juga disarankan untuk membawa soda atau susu. Informasi tersebut dipertukarkan melalui jejaring sosial Facebook.

Aktivis yang biasanya menghadapi risiko ditahan saat berdemonstrasi juga bisa menyebarkan ide-ide melalui internet. Hal ini pernah dilakukan Ahmad Maher, aktivis pergerakan yang membangun grup di Facebook dan menggunakannnya sebagai simpul komunikasi gerakan. Teknologi internet juga dimanfaatkan untuk penggalangan dana. Di Mesir, dana hasil penggalangan tersebut digunakan untuk pembelian selimut dan tenda bagi aktivis yang bertahan di Lapangan Tahrir (Leksono, 2011).

Jejaring sosial memiliki peran yang luar biasa terhadap revolusi di Timur Tengah. Beberapa ahli menyebut dampak terbesar jejaring sosial terhadap revolusi tersebut adalah ketika pemerintah mulai melarang akses ke jejaring sosial. Di Tunisia, beberapa orang menyebut perlawanan terhadap upaya pemerintah memblok atau menutup beberapa jaringan sebagai WikiLeaks Revolution. Ketika pemerintah Tunisia memblok beberapa laman dan menangkap sejumlah aktivis, para pemuda justru semakin terdorong untuk membalas perlakuan pemerintah dengan berbagi informasi melalui blog, Facebook dan Twitter. Di Mesir, kemarahan publik membesar ketika pemerintah memblok Twitter dan Facebook, yang kemudian disusul dengan dimatikannya koneksi internet. Meskipun media sosial membantu para pemrotes untuk mengorganisasi gerakan dan saling berkomunikasi, namun tampaknya peran terbesar media sosial justru saat mereka menghilang. Slogan mutakhir di internet mengenai hal itu pernah dicetuskan oleh The Economist (2011): “Jika pemerintah Anda menutup internet, tiba waktunya untuk menutup pemerintahan tersebut."

Semangat untuk revolusi telah bergerak hingga melewati batas-batas transnasional satu negara. Semua revolusi tersebut digerakkan oleh para pemuda melalui sarana dan prasarana yang lebih modern seperti jejaring sosial di internet dan pesan singkat via ponsel. Seorang pengajar ekonomi dan aktivis politik dari Bahrain, Ala'a Shehabi, berkata bahwa "[w]hether you're in Tunis or in Cairo or in Manama, young Arabs are all on the same wavelength"(Ghosh, 2011b). Semangat yang kemudian bertransformasi menjadi sebuah perlawanan rakyat terhadap rezim diktator 
di Tunisia tersebut telah menyebar menjadi sebuah gerakan massa.

Dalam konteks ini, aktivisme transnasional memiliki peran penting, terutama dalam memanfaatkan fungsi dari jejaring sosial sebagai media baru. Artinya, meminjam istilah Habermas (2010), gerakan massa dapat dibaca sebagai perwujudan dari ruang publik yang bertransformasi secara politis dan memberikan ruang-ruang politik bagi masyarakat. Transformasi politik ruang publik inilah yang membuka kemungkinan adanya proses demokratisasi di Timur Tengah.

\section{Kesimpulan}

Tulisan ini telah menguraikan peran-peran media baru dalam revolusi Arab Spring di tahun 2011 dan implikasi politiknya bagi perkembangan gerakan massa di kawasan tersebut. Secara umum, tulisan ini berkesimpulan bahwa gerakan massa yang berani menentang pemerintah dinegara-negara Timur Tengah, seperti Mesir, Tunisia, dan Libya, dilatarbelakangi oleh sejumlah faktor ketidakpuasan sosial, diantaranya tingkat pengangguran yang tinggi, kemiskinan, harga-harga kebutuhan pokok yang mahal, dan korupsi rezim. Bersamaan dengan hal tersebut, ketidakpuasan politik juga melingkupi rakyat karena otoriterisme yang dijalankan rezim politik yang berkuasa selama ini justru mengekang dan mengurangi hak-hak berpendapat, dan pada gilirannya menimbulkan kekecewaan dan protes terhadap rezim politik.

Ketidakpuasaan dalam kedua aspek di atas membuat gerakan massa di Timur Tengah menuntut suatu perubahan. Dari sisi sosial, rakyat jelas menginginkan kondisi yang lebih sejahtera, bila perlu dengan pergantian rezim. Dari sisi politik, rakyat mulai menginginkan sebuah upaya menuju tatanan demokrasi yang sering mereka lihat dan dengar di Barat, namun tidak mereka lihat di negeri sendiri. Semangat gerakan massa di Tunisia dan Mesir pun menyebar ke negara-negara Timur Tengah lainnya. Kata kunci dalam penyebaran tersebut adalah aktivisme transnasional dan teknologi digital dalam konteks ruang publik. Aktivisme transnasional mengambil bentuk laporan yang terus-menerus dari berbagai media mengenai apa yang tengah terjadi selama berbulanbulan di Tunisia dan Mesir. Hal itu diikuti penyebaran ide-ide demokrasi dan penyuaraan hak-hak rakyat melalui internet.

Letak geografis negara-negara tersebut yang berdekatan, sistem politik yang hampir sama, dan rezim otoriter yang sama-sama tidak membuat rakyat puas, membuat ide-ide perlawanan terhadap rezim sangat nyata dan terasa pas dengan konteks. Ketidakpuasan ini kemudian berakumulasi dan menemui momentumnya pada medio 2010-2011. Pertanyaannya, mengapa 'perubahan politik' tersebut bisa menjalar ke beberapa negara? Penjelasan yang muncul adalah bahwa para aktivis prodemokrasi saling bertukar informasi dan memanfaatkan ruang publik yang tersedia; mereka mampu memanfaatkannya secara efektif. Ruang publik yang dimaksud adalah jejaring atau media sosial dan blog. Dengan medium berupa teknologi digital, pemerintah sulit menangkal gelombang protes dan demonstrasi ketidakpuasan rakyat di Timur Tengah.

Dalam kasus revolusi di Timur Tengah ini terdapat suatu fenomena menarik, yaitu bahwa teknologi mulai memegang peranan penting dan rakyat, khususnya generasi muda, semakin pandai dalam memanfaatkan teknologi. Dengan masih terus berlangsungnya proses revolusi di Timur Tengah, masih banyak yang bisa diamati dari perkembangan peran pemuda dan teknologi dalam penelitian-penelitian selanjutnya. Satu catatan penting bisa ditarik dari proses ini: jejaring sosial seperti Facebook dan Twitter, yang baru muncul di abad ke-21, telah mengubah cara-cara perjuangan rakyat dalam dimensi yang lebih luas sebagai usaha pemenuhan hak-hak dalam konteks ruang 
publik, melalui cara-cara baru yang saat ini sulit dibendung oleh pihak mana pun.

\section{Daftar Pustaka}

Al-Anani, Khalil. (2008). Brotherhood Bloggers: A New Generation Voices Dissent. Arab Insight, 2 (1), 29-38.

"A Coup is Reported in Tunisia."(1987). New York Times, November 7. Diakses 2 Maret 2011.<http://www.nytimes.com/1987/11/07/ world/a-coup-is-reported-in-tunisia. html?pagewanted $=1>$.

“Bouzizi, Pahlawan Revolusi Tunisia.” (2011). British Broadcasting Channel. Diakses 2 Maret 2011.

$<$ http://www.bbc.co.uk/indonesia/ majalah/2011/01/110123_tunisia_pahlawan. shtml>

“Egypt, Is The Party Over?". 2011. The Middle East, March.

"Facebook, Twitter, and Youtube Now Become A New Weapon." (2011). Al-Jazeera.

Arfani, Riza Noer. 6 Februari 2011. Pandora Timur Tengah. Kedaulatan Rakyat

Ahmed, Amel dan Giovanni Cappocia. (2014). The Study of Democratization and Arab Spring. Middle East Law and Governance 6: 1-31.

Angrist, Michelle Penner. (2011). Mourning in Tunisia: The Frustations of Arab World Boil Over. Foreign Affairs. (Online). (http://www. foreignaffairs.com/articles/67321/michelepenner-angrist/morning-in-tunisia).

Chamkhi, Tarekh. (2012). Neo-Islamism PostArab Spring. Paper presented at Australian Political Science Association Annual Conference, Murdoch University, Perth.

Elliot, Michael. 7 Maret 2011. Learn to Love The Revolution. Time.

Grand, Stephen R. (2011). Starting from Egypt: The Fourth Wave of Democratization?. The Brookings Institution. (Online). (http:// www.brookings.edu/opinions/2011/0210_ egypt_democracy_grand.aspx, diakses 2 Maret 2011)
Ghosh, Bobby. 21 Februari 2011a. Revolution Delayed. Time.

. 28 Februari 2011b. Rage, Rap, and Revolution. Time.

Hadiz, Vedi R. (2003). Reorganising Political Power in Indonesia: A Reconsideration of so-called 'Democratic Transitions'. The Pacific Review, 16 (4): 591-611 (2011). No Turkish Delight: The Impasse of Islamic Party Politics in Indonesia. Indonesia 92: 1-18.

Habermas, Jurgen. (2010). The Structural Transformation of the Public Sphere: An Inquiry into a Category of Bourgeois Society, terjemahan Indonesia. Yogyakarta: Kreasi Wacana.

Halliday, Fred. (2005). The Middle East in International Relations: Power, Politics and Ideology. Cambridge University Press.

Hanouz, M.D. dan S. Khatib. (2011). The Arab World Competitiveness Review. World Economic Forum. Davoz: WEF.

Hardiman, F. Budi. (2010). Demokrasi Deliberatif: Menimbang Negara Hukum dan Ruang Publik dalam Teori Diskursus Jurgen Habermas. Yogyakarta: Kanisius.

(1998). Kritik Ideologi. Yogyakarta: Kanisius.

Howard, Philip N. and Muzammil M. Hussain. (2013). Democracy's Fourth Wave? Digital Media and the Arab Spring. Oxford: Oxford University Press.

Huntington, Samuel. (1993). The Third Wave: Democratization in the Late 21th Century. Oklahoma: Oklahoma University Press.

Hauslohner, Abigail. 18 April 2011. Democracy, Egyptian Style. Time.

Kurzman, Charles. (2012). TheArabSpring:Ideals of the Iranian Green Movement, Methods of the Iranian Revolution. International Journal of Middle East Studies 44 (1): 162-165.

International Monetary Fund. (2011). World Economic and Financial Survey: Regional Economic Outlook Middle East and Central Asia. Washington, DC: IMF Publications. 
"Internet Blackouts: Reaching for the Kill Switch" The Economist, 12 February 2011.

Jackson, Robert dan George Sorensen. (2007). Introduction to International Relations. New York: Oxford University Press.

Kellner, D. (2011). Habermas, The Public Sphere and Democracy: A Critical Intervention. UCLA EDU. (Online). (<http:// gseis.ucla.edu/faculty/kellner/essays/ habermaspublicspheredemocracy.pdf $>$ diakses 10 Juli 2011).

Kitchen, Nicholas et al. (2011). After the Arab Spring: Power Shift in the Middle East?. IDEAS Report, London: LSE.

Leksono, Ninok. 16 Februari 2011. Teknologi Digital dalam Revolusi Politik. Kompas.

Malek, Adeel dan Bassam Awadalah. (2011). The Economics of Arab Spring. CSAE Working Paper WPS 2011-23. Oxford: Center for the Study of African Economics, University of Oxford.

Pepinsky, Tomas. (2013). There is No Indonesian Model for the Arab Spring. Foreign Affairs. (Online). (<http://foreignpolicy. com/2013/02/27/there-is-no-indonesiamodel-for-the-arab-spring/>, diakses 10 Juli 2011).

Ramadan, Tariq. (2012). Islam and the Arab Awakening. Oxford: Oxford University Press.
Said, Edward. (1978). Orientalism. New York: Penguin.

Singh, Abhisek and Gopal Thakur (2013). New Media Technology as Public Sphere for Social Changes: A Critical Study. Journal of Indian Research 1 (2): 38-43.

Sihbudi, M. Riza. (1991). Islam, Dunia Arab, Iran: Bara Timur Tengah. Bandung: Penerbit Mizan.

Snow, David and Robert Benford. (2000). Framing Processes and Social Movements: An Overview and Assessment. Annual Review of Sociology 26. pp. 611-639

Tarrow, Sidney. (2005). The New Transnational Activism. Cambridge: Cambridge University Press.

Internasionalé. 3 Maret 2011. Timur Tengah, dari Revolusi ke Revolusi.

Transparency International. 2010. Corruption Perception Index 2010 Results. (Online). (<http://www.transparency.org/policy_ research/surveys_indices/cpi/2010/results>, diakses 4 Juni 2011).

Wickham, Carrie Rosefsky. (2003). Mobilizing Islam: Religion, Activism, and Political Change in Egypt. New York: Columbia University Press.

Zahid, Muhammad. (2010). The Muslim Brotherhood and Egypt's Succession Crisis: The Politics of Liberalisation and Reform in the Middle East. London: IB Tauris. 